\title{
Inquiry-Based Learning Implementation to Improve Critical Thinking of Prospective Teachers
}

\author{
Damajanti Kusuma Dewi, Wayan Ardhana, Irtadji, Tutut Chusniyah, and Ambar Sulianti
}

\begin{abstract}
Teachers must possess critical thinking skills to become good facilitators in the education process to produce students with high-order thinking skills. This research aims to evaluate the implementation of the inquiry-based learning (IBL) method in improving the critical thinking (CT) skills of prospective teachers with their own learning styles. An experimental study is the research method used in this research with the matching-only pretest-posttest with a control group design. The selected participants consisted of two groups of prospective teachers, a total of 76 people with low critical thinking skills and 50 people with very low skills. The experimental group was given the IBL method, while the control group was given the problem-based learning method, which refers to the latest curriculum. Treatment is given for 8 weeks. The statistical analysis used includes Wilcoxon, Mann-Whitney, and Kruskal-Wallis followed by post hoc. The results of this study show an increase in critical thinking in both the experimental group and the control group. However, the increase in the experimental group was significantly higher than the control group. The increase in experimental group with low and very low $\mathrm{CT}$ group did not differ significantly. On the other hand, in the control group, the increase in CT in the low group was significantly higher than the very low group. Furthermore, the Kruskal-Wallis difference test in the experimental group based on learning styles showed that prospective teachers with converging learning styles were more able to follow the IBL method compared to other learning styles.
\end{abstract}

Index Terms-Inquiry-based learning, critical thinking, prospective teachers, learning style.

\section{INTRODUCTION}

Although the Indonesian government implemented several education management revisions, the learning outcomes have not been satisfactory. This is according to the 2018 Program for International Student Assessment (PISA) survey, a 3-year survey of 15-year-old students assessing their acquisition level of the critical knowledge and skills essential for full participation in society [1]. Furthermore, Indonesia needs to improve its current education system and management, especially after emerging in the 74th position out of the 79 countries that participated in the PISA assessment. This position was even below their ranking in the previous 3 years [2]. One of the causes for this drop is the limited training for Indonesian students in solving contextual problems.

Manuscript received March 24, 2021; revised June 23, 2021.

The authors are with Universitas Negeri Malang, Indonesia (e-mail: damajantikusuma@unesa.ac.id,_wayanardhanaunm@gmail.com, ir_ta_dji@yahoo.com, tututchusniyah@gmail.com) and UIN Sunan Gunung Djati, Indonesia (e-mail: ambarsulianti@uinsgd.ac.id).
Therefore, they require high order thinking skills, such as identification, argumentation, and creativity for effective problem-solving.

Bloom's taxonomy states that human thinking skills are classified into low-order thinking skills (LOTS) and higher-order thinking skills (HOTS). Students are taught the significance of positive educational development, which implies that thinking skills have a close relationship with learning. Furthermore, research in Papua shows a very significant relationship between HOTS and academic achievement [2]. Based on HOTS, students need to understand, summarize, and relate whatever they learn by analyzing it through problem-solving. On the contrary, based on LOTS, they acquire and memorize what has been learned and relate it to previous knowledge to achieve their goals. However, at high-level thinking, they need to use logic in mastering concepts to solve more complex problems [3].

Several components are needed to produce quality education, including school leadership, classroom management, application of teaching materials, and the role of teachers [4]. One of the vital and generally discussed factors related to education quality is the teacher's role. In Indonesia, teacher quality problems have always been a serious concern of education. Improving the learning quality with an impact on education is to be accompanied by an increase in their capabilities and competencies. This needs to be applied in developing innovative and creative learning activities to produce competent graduates [5]. Teachers accustomed to using HOTS influence the thinking skills of students [6]. They must have good critical thinking skills to experience higher-order thinking processes [7]. Critical thinking (CT) is included in higher-order thinking skills [8]. Being one of the HOTS, critical thinking should be central in learning development because it gives humans life skills, creativity, and innovation in solving complex real-life problems [9]. Moreover, critical thinking capacity is an indicator of higher-order thinking skills [10], [11]. CT is the ability and willingness to be open-minded to ideas regardless of one's beliefs and to engage in reflective and balanced thinking [12]. Through CT, students explore a problem, question, or situation, integrate all available related information, arrive at a solution or hypothesis, and justify one's position [13]. Given these reasons, prospective teachers must have good critical thinking skills.

The improvement of education quality cannot be separated from the twenty-first-century skills framework, which includes learning skills, innovation skills, comprising communication, collaboration, creativity, and critical thinking. Since 2013, the Indonesian education curriculum has shifted from teacher-based to student-based method [14], 
[15]. The last curriculum (2019 curriculum revision 2013) focuses on character education, literacy, and competence. This curriculum applies student-centered learning to improve their HOTS abilities. Student-centered learning is adopted by many schools and education systems that promote problem-based, project-based, case-based, and inquiry learning worldwide [16], [17].

Problem-based learning (PBL) is the student-based learning approach widely used in Indonesia. PBL was implemented in more than 17,000 studies in Indonesia since 2013 through the Google Scholar database source. PBL helps students to be active in learning [18]. By definition, PBL is a learning method around problem-solving activities by delivering arguments or ideas and communicating to peers by interacting with various classroom components. Moreover, it involves reflecting on what students should follow to solve the problems raised by the teacher [19]-[22]. In the PBL method, participants are motivated to learn in groups since the social interaction reduces students' nervousness during the learning process. In the neuroeducation points of view, excessive worry results in anxiety, which then becomes a body reaction to stress through the neurochemical system and certain brain regions. The hippocampus, amygdala, and medial prefrontal cortex are the brain parts involved in stress response. Moreover, cortisol and norepinephrine are released through the corticotropin-releasing factor and hypothalamic-pituitary-adrenal axis [23]. In general, anxiety is related to processing worried mind preferences or treated stimuli that damage cognitive control [24]. A study correlating anxiety to brain wave observation through Electroencephalography shows that anxiety affects memory strength [25].

Meanwhile, research in Indonesia and the results of the PBL meta-analysis over a 7-year period show that PBL has not been able to improve the collaboration skills of participants. Constraints in implementing PBL in Indonesia are mainly due to low levels of self-confidence [26]. On the other hand, one of the student-based methods carried out independently rather than in groups is inquiry-based learning (IBL), which is a student-centered constructivist pedagogy that puts students in control of their learning. Students develop their questions to examine, engage in independent investigation, and collaborate with one another [27]-[29]. IBL requires students to actively build their own knowledge, reason, and compare new with initial concepts. Therefore, IBL trains students' thinking skills in solving problems and directs them to become independent learners through a series of activities [30]. A study in Malang, Indonesia, recommended that teachers empower their students' HOTS abilities through inquiry/discovery classes to create meaningful student-centered learning [31]. Other research showed that students implemented with the inquiry learning method exhibited high motivation, enjoyment, and creativity. High motivation contributes to the learning process and improves student achievement. Moreover, intrinsic motivation fosters high cognitive engagement in the classroom, resulting in adaptive outcomes [32].

An essential condition for learning is an intense interest in responding to educational activities. Student interest in learning correlates with cognitive and affective factors, which in turn affect the learning progress [33]. Research has been conducted on the relationships between IBL and critical thinking worldwide. However, there has never been a report on its implications for various learning styles in Indonesia. The learning style theory states that students have individual modes and learn more quickly and effectively when having the material that fits their styles. The interaction of the student's previously acquired knowledge, motivation, and messages impacts message delivery [34]. Learning styles are related to reading and listening achievement because this determines students' understanding. They feel comfortable absorbing, obtaining, understanding, and processing information in their way [35]. Learning style determines the instruction given, and students need to be taught and assessed in a way that suits them individually.

Learning styles, also called cognitive strategies, direct an individual's management of the internal processes. These processes relate to learning, thinking, memory, abilities influenced by innovative strategies, and response organization [36]. Learning styles are cognitive, affective, and physiological features that indicate how students perceive interactions and respond to their learning environment [37] Kolb (1984) states that learning style is a personal way of processing information, feelings, and behavior in learning situations [38].

Kolb stated four learning styles, namely, converging, diverging, assimilating, and accommodating [39]. Kolb defined converging learning as an approach where students prefer to deal with applications and problems to make decisions. Students enjoy technical tasks and think analytically, though they generally have difficulty seeing problems from a different perspective [40]. Hence, convergent learners use common sense to understand through abstract conceptualization and process information through active experiments [41]. Additionally, they are less concerned with social and relational problems and have a career in technology [42]. Assimilating learning was defined as an approach used by people with several abilities, such as gathering information to create a global view and make theoretical models [39]. The assimilator has an abstract conceptualization or reflective observation as the dominant learning ability [40], [43]. The accommodating learning style is hands-on, and accommodators rely more on intuition than logic [40]. Moreover, accommodators understand through real experiences and process information through active experiments [41]. Kolb defined divergent learners as students that prefer collecting information widely and are imaginative thinkers [39]. Furthermore, they behave naturally and use their imagination in solving problems [40].

\section{OBJECTIVES OF THE STUDY}

Based on the research background, the objectives of this study are as follows:

1) Differentiating the IBL and PBL methods in increasing critical thinking of prospective teachers

2) Analyzing the increasing critical thinking of prospective teachers with very low and low CT

3) Evaluating the interaction of student learning styles in accepting the IBL method 


\section{RESEARCH METHODS}

\section{A. Research Design}

This research is an experimental study with the matching-only pretest-posttest control group design. The research used the PBL method as the most recommended student-based learning approach in Indonesia. The target population was the first semester prospective teacher students in one of the education studies programs. Fig. 1 shows the research design.

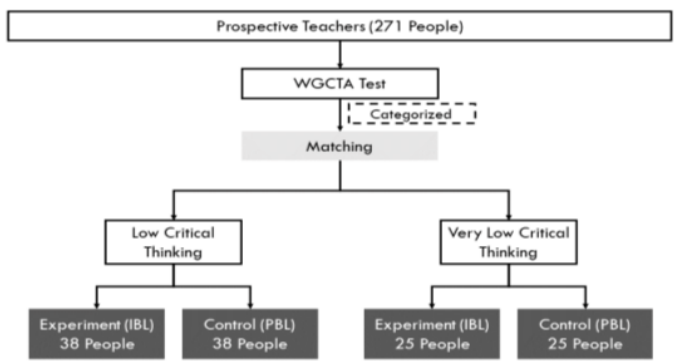

Fig. 1. Research design.

The first step was taking the subject from the prospective teachers recently accepted in one of Indonesia's education faculties. Participants were given an initial critical thinking ability test that functioned in a matching technique. The selected participants comprised a group of prospective teacher students with low and very low critical thinking skills Furthermore, using the matching technique, the sample was divided into experimental and control groups. The IBL learning model was used in the experimental group, while the PBL model was used on the control group. The treatment was given for eight meetings, each lasting $100 \mathrm{~min}$ per week. The two groups then underwent the treatment process and given the posttest.

\section{B. Research Procedures}

The subject tried out in both groups was educational psychology, which is compulsory for prospective teachers. The subject is useful in teaching applications to increase students' HOTS when they graduate as teachers. The experimental group was treated using the IBL, while the control group was treated according to the 2013 revised 2019 curriculum, the PBL. Table I presents the teaching procedure.

TABLE I: RESEARCH PROCEDURE

\begin{tabular}{|c|c|c|c|}
\hline \multicolumn{2}{|c|}{ PBL } & \multirow{2}{*}{\multicolumn{2}{|c|}{$\begin{array}{l}\text { IBL } \\
\text { Implementation }\end{array}$}} \\
\hline Steps & Implementation & & \\
\hline $\begin{array}{l}1 . \\
\text { Orientation } \\
\text { of problem }\end{array}$ & $\begin{array}{l}\text { a. Educators form } \\
\text { the class into several } \\
\text { groups, where each } \\
\text { group contains 5-6 } \\
\text { members }\end{array}$ & 1. Engage & $\begin{array}{l}\text { The teacher's role: } \\
\text { - Establish rules and } \\
\text { procedures that must } \\
\text { be done by students }\end{array}$ \\
\hline & $\begin{array}{l}\text { b. Educators give } \\
\text { problems, in various } \\
\text { forms, including } \\
\text { videos, research } \\
\text { results, and } \\
\text { interviews, among } \\
\text { others }\end{array}$ & & $\begin{array}{l}\text { The role of students: } \\
\text { - Focus attention on } \\
\text { objects, problems, } \\
\text { situations, or events } \\
\text { given by the teacher } \\
\text { - Connect objects, } \\
\text { problems, and } \\
\text { existing situations } \\
\text { with past }\end{array}$ \\
\hline
\end{tabular}

\begin{tabular}{|c|c|c|c|}
\hline & & & $\begin{array}{l}\text { experiences } \\
\text { - Learn to find things } \\
\text { related to new } \\
\text { information with old } \\
\text { information and } \\
\text { manifest in the form } \\
\text { of questions }\end{array}$ \\
\hline \multirow[t]{2}{*}{$\begin{array}{l}\text { 2. Divide } \\
\text { and select } \\
\text { problems }\end{array}$} & $\begin{array}{l}\text { a. Educators provide } \\
\text { opportunities for } \\
\text { groups and divide } \\
\text { tasks to each } \\
\text { member }\end{array}$ & $\begin{array}{l}2 . \\
\text { Exploration }\end{array}$ & $\begin{array}{l}\text { Equilibration phase } \\
\text { (reduce the curiosity } \\
\text { of the questions that } \\
\text { have been arranged) } \\
\text { The role of } \\
\text { educators: } \\
\text { - Develop an } \\
\text { environment that can } \\
\text { support student } \\
\text { activities so that they } \\
\text { are able to find } \\
\text { answers }\end{array}$ \\
\hline & $\begin{array}{l}\text { b. Educators ask } \\
\text { students to choose a } \\
\text { major problem or } \\
\text { minor problem, } \\
\text { which will be } \\
\text { focused on }\end{array}$ & & $\begin{array}{l}\text { The role of students: } \\
\text { - Search for answers } \\
\text { to existing questions }\end{array}$ \\
\hline \multirow[t]{2}{*}{$\begin{array}{l}\text { 3. Analyze } \\
\text { the problem }\end{array}$} & $\begin{array}{l}\text { a. The educator } \\
\text { applies the } \\
\text { brainstorming } \\
\text { method (without } \\
\text { criticism) to the } \\
\text { problems that have } \\
\text { been selected by } \\
\text { each student }\end{array}$ & $\begin{array}{l}3 . \\
\text { Explanation }\end{array}$ & $\begin{array}{l}\text { The phase explains } \\
\text { and clarifies the } \\
\text { concept. } \\
\text { The role of } \\
\text { educators: } \\
\text { - Direct students' } \\
\text { attention to specific } \\
\text { aspects between the } \\
\text { first experience and } \\
\text { the situation during } \\
\text { exploration, by } \\
\text { asking students to } \\
\text { apply the questions } \\
\text { they have and } \\
\text { explain scientific } \\
\text { terms directly, } \\
\text { explicitly, and } \\
\text { formally }\end{array}$ \\
\hline & $\begin{array}{l}\text { b. Educators } \\
\text { facilitate students to } \\
\text { be able to compare } \\
\text { the results of } \\
\text { thinking between } \\
\text { before and after } \\
\text { brainstorming, } \\
\text { followed by } \\
\text { note-taking, } \\
\text { comparing personal } \\
\text { and group opinions, } \\
\text { and then presenting } \\
\text { it }\end{array}$ & & $\begin{array}{l}\text { The role of students: } \\
\text { - Describe } \\
\text { exploratory } \\
\text { experiences and } \\
\text { experiences when } \\
\text { getting explanations } \\
\text { from the educator }\end{array}$ \\
\hline $\begin{array}{l}4 . \\
\text { Searching } \\
\text { for answers } \\
\text { to existing } \\
\text { questions }\end{array}$ & $\begin{array}{l}\text { Educators } \\
\text { encourage } \\
\text { participants to find } \\
\text { common answers, } \\
\text { assess } \\
\text { problem-solving } \\
\text { skills, discard } \\
\text { irrelevant opinions, } \\
\text { write down reasons } \\
\text { for changing results, } \\
\text { and prepare } \\
\text { appropriate } \\
\text { presentations }\end{array}$ & $\begin{array}{l}4 . \\
\text { Elaboration }\end{array}$ & $\begin{array}{l}\text { Participants bring } \\
\text { together experiences } \\
\text { and new } \\
\text { understanding to } \\
\text { form new knowledge }\end{array}$ \\
\hline
\end{tabular}




\begin{tabular}{lll}
\hline 5. & $\begin{array}{l}\text { a. Educators give } \\
\text { opportunities for } \\
\text { other groups to } \\
\text { provide opinions } \\
\text { (accept, reject, or } \\
\text { provide additional) } \\
\text { by supplying } \\
\text { reasons and } \\
\text { evidence }\end{array}$ & $\begin{array}{l}\text { Participants assess } \\
\text { ideas and concepts, } \\
\text { where students learn } \\
\text { to assess the } \\
\text { knowledge, they } \\
\text { already have. }\end{array}$ \\
& $\begin{array}{l}\text { Students can receive } \\
\text { feedback on the } \\
\text { clarity of the } \\
\text { knowledge they } \\
\text { already have }\end{array}$ \\
\hline & & \\
b. Participants & \\
reflect, write down & & \\
what they have & \\
learned, and & \\
evaluate & \\
\hline
\end{tabular}

\section{Statistical Analysis}

The statistical analysis used aligned with the research objectives. The Wilcoxon test was used to examine the difference in critical thinking before and after treatment in each group based on the non-normality of the data distribution results. Moreover, the Mann-Whitney difference test was used to compare CT teacher candidates' improvements between the IBL and PBL groups. The Kruskal-Wallis test was used to examine an increase in CT in the IBL and PBL groups in the low and very low CT groups. In addition, it was used to assess the $\mathrm{CT}$ increases in different learning styles with IBL method, followed by a post hoc test.

\section{RESULTS}

This section presents descriptive and analytical results according to the research objectives. Table II presents the descriptive characteristics of the assessment results of critical thinking skills in the experimental and control groups.

\begin{tabular}{llclc}
\multicolumn{4}{c}{ TABLE II: CT BEFORE AND AFTER TREATMENT } \\
\hline \hline CT Test & Mean & $\begin{array}{c}\text { Tests of } \\
\text { normality } \\
(\mathbf{p})\end{array}$ & $\begin{array}{c}\text { Difference } \\
\text { test } \\
\text { analysis }\end{array}$ & Sig. \\
\cline { 1 - 3 } IBL pretest & 7.21 & 0.000 & Wilcoxon & 0.000 \\
\cline { 1 - 3 } IBL posttest & 10.37 & 0.048 & Wilcoxon & 0.000 \\
\cline { 1 - 3 } PBL pretest & 6.89 & 0.005 & & \\
\hline PBL posttest & 9.10 & 0.009 & &
\end{tabular}

As presented in Table II, CT increased in both the IBLand PBL-treated groups. Furthermore, the Mann-Whitney test was performed to see which group had significantly higher CT changes. The results of the Mann-Whitey test are presented in Table III.

TABLE III: CT IN THE EXPERIMENT AND CONTROL GROUP

\begin{tabular}{|c|c|c|c|c|}
\hline Group & Mean & Median & Difference test analysis & Sig. \\
\hline $\begin{array}{l}\text { Experim } \\
\text { ent }\end{array}$ & 3.159 & 3 & \multirow[t]{2}{*}{ Mann-Whitney } & \multirow[t]{2}{*}{0.000} \\
\hline Control & 2.238 & 2 & & \\
\hline
\end{tabular}

The results of statistical analysis in Table III, show that the increase in CT in the group using IBL was significantly higher than the group using PBL. For clarity, Fig. 2 shows the enhancement of CT in each group.
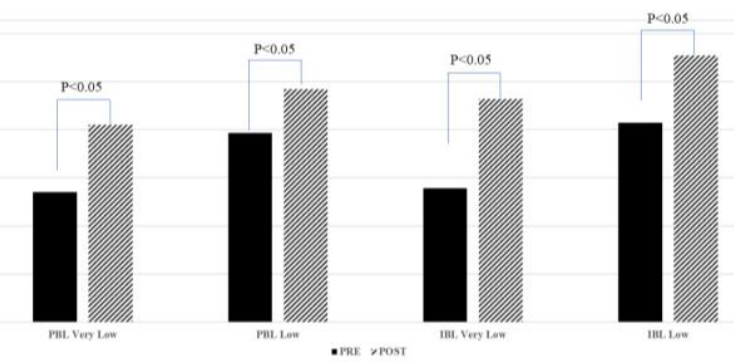

Fig. 2. Difference of CT in all groups.

Fig. 2 shows an increase in $\mathrm{CT}$ in the entire research group. Furthermore, Table IV presents the descriptions of each group with low and very low CT.

TABLE IV: DESCRIPTIVE CRITICAL THINKING IN ALL GROUPS

\begin{tabular}{ccccccccc}
\hline \hline \multirow{2}{*}{ Item } & \multicolumn{4}{c}{ IBL } & \multicolumn{5}{c}{ PBL } \\
\cline { 2 - 9 } & \multicolumn{2}{c}{ PRE } & \multicolumn{2}{c}{ POST } & \multicolumn{2}{c}{ PRE } & \multicolumn{2}{c}{ POST } \\
\cline { 2 - 9 } & $\begin{array}{c}\text { Very } \\
\text { Low }\end{array}$ & Low & $\begin{array}{c}\text { Very } \\
\text { Low }\end{array}$ & Low & $\begin{array}{c}\text { Very } \\
\text { Low }\end{array}$ & Low & $\begin{array}{c}\text { Very } \\
\text { Low }\end{array}$ & Low \\
\hline$\mu$ & 5.56 & 8.29 & 9.28 & $\begin{array}{c}11.0 \\
8\end{array}$ & 5.40 & 7.87 & 8.20 & 9.68 \\
\hline SD & 0.87 & 0.89 & 1.62 & 1.92 & 0.70 & 0.96 & 1.38 & 1.165 \\
\hline Med & 5 & 8 & 9 & 11 & 6 & 8 & 8 & 10 \\
\hline Min & 4 & 7 & 7 & 7 & 4 & 7 & 7 & 7 \\
\hline Max & 7 & 10 & 12 & 14 & 6 & 10 & 12 & 12 \\
\hline $\mathrm{N}$ & 25 & 38 & 25 & 38 & 25 & 38 & 25 & 38 \\
\hline \hline
\end{tabular}

The Kruskal-Wallis test was performed to analyze the differences in each group, as presented in Table $\mathrm{V}$, and was followed by Mann-Whitney's post hoc analysis in Table VI.

TABLE V: THE KRUSKAL-WALLIS TEST OF CT

\begin{tabular}{ll}
\hline \hline & Difference of CT \\
\hline Kruskal-Wallis H & 82.915 \\
\hline df & 3 \\
\hline Asymp. Sig. & .000 \\
\hline \hline a. Kruskal-Wallis test. \\
b. Grouping variable.
\end{tabular}

TABLE VI: THE MANN-WhitNey Post HoC TEST

\begin{tabular}{|ccc|}
\hline Group & Ave Rank & Median $($ min, max $)$ \\
\hline IBL very low CT & 54.72 & $4\left(1,7^{\text {) }}\right.$ \\
\hline IBL low CT & 41.08 & $3(0,6)^{\mathrm{ab}}$ \\
\hline PBL very low CT & 30.5 & $3(1,6)^{\mathrm{b}}$ \\
\hline PBL low CT & 107.49 & $2(0,4)^{\mathrm{c}}$ \\
\hline \hline
\end{tabular}

The same letter in Table VI indicates no significant difference. Thus, Table VI shows that the increase in CT in the IBL group did not differ significantly between the low CT group and the very low CT group. On the other hand, in the PBL group, the increase in the low CT group was significantly higher than the very low CT group. Furthermore, the Kruskal-Wallis test is performed, as presented in Table VII.

The results of the Kruskal-Wallis difference test show significant differences in CT in student learning styles. Then to see which groups of learning styles are significantly different, followed by post hoc using Mann Whitney test which is shown in Table VIII. 
TABLE VII: THE KRUSKAL-WALLIS TEST OF LEARNING SYTLE

Learning Style

\begin{tabular}{lc} 
& Learning Style \\
\hline Kruskal-Wallis H & 25.285 \\
\hline Df & 3 \\
\hline Asymp. Sig. & .000 \\
\hline \hline $\begin{array}{l}\text { a. Kruskal-Wallis test. } \\
\text { b. Grouping variable. }\end{array}$
\end{tabular}

TABLE VIII: Post Hoc TEST OF LEARNING SyTLE

\begin{tabular}{lcc}
\hline \hline Group & Ave Rank & Median (min, max) \\
\hline Converging & 48.71 & $5(3,6)^{\mathrm{a}}$ \\
\hline Accommodating & 28.43 & $3(0,7)^{\mathrm{b}}$ \\
\hline Assimilating & 24.63 & $3(0,4)^{\mathrm{b}}$ \\
\hline Diverging & 20.31 & $2(0,4)^{\mathrm{b}}$ \\
\hline \hline
\end{tabular}

The results of the post hoc analysis show that subjects with a converging learning style have a higher critical thinking increase compared with other learning styles.

\section{DISCUSSION}

This study examines critical thinking improvement in prospective teachers by comparing the IBL experimental and PBL control treatment methods. This refers to the 2013 Indonesian education curriculum revised in 2019, where teachers should not use conventional teacher-centered learning. PBL is the most student-centered learning method used in Indonesia. According to the first finding, the IBL and PBL groups showed an increase in prospective teachers' critical thinking skills.

The student-centered learning teaching approach allows to explore and obtain their own in-depth knowledge and improve learning quality [44]. Moreover, this approach focuses on in-depth learning and understanding and increases students' motivation, making them independent and responsible. The application of this approach influences students' perceptions of learning activities. Critical thinking is a cognitive activity that is related to using the mind concerning education. Learning to think in a vital, diagnostic, and evaluative way means using mental processes, such as attention, categorization, selection, and judgment [45]. Creating a comfortable atmosphere for students to face integrative activities increases their motivation in reading achievement [46].

IBL and PBL increase the curiosity of student teacher candidates. This is supported by the mismatch theory, stating that curiosity is generated by a desire to understand more, which arises when expectations are violated [47]. Moreover, this theory aligns with that of Oudeyer et al., which showed that increased curiosity was correlated with higher activity in the striatum and inferior frontal cortex [48]. The feedback in the implementation of IBL and PBL stimulates curiosity and increases the knowledge gap salience. In line with these results, several studies have shown that students that guess feedback improve learning outcomes [49].

The second finding is that CT in the treatment group showed a significant improvement than in the control group. IBL improves CT than PBL for both prospective teachers with low and very low CT. This finding aligns with that of Llewellyn and Siburian et al., which recommended applying inquiry learning for students to explore and empower their thinking skills actively. Therefore, inquiry learning strategies are more meaningful and useful in creating critical and creative thinking skills [50]. Research shows the effectiveness of the inquiry-based learning model in developing students' critical thinking skills [51]. This model is a series of learning activities that emphasize the critical thinking process and analysis in problem-solving [52]. In line with this, Hairida (2016) concluded that inquiry-based learning is effective for developing students' critical thinking [53]. The model allows and helps students gain an understanding of the scientific method to develop critical thinking skills [54].

Critical thinking corresponds to the threshold at which transformation becomes the most distinctive characteristic. This is because obtaining the threshold involves a series of continuous shifts. Progress is made through effective teaching and learning. It has been determined that PBL encourages critical thinking [55].

Problem-based learning improves students' lifelong skills, such as critical thinking, which they use in the learning process. This is useful in the knowledge construction process by relating current and previous knowledge [18].

The PBL method control group was divided into groups. In these groups, participants that seemed confident appeared as the mainstay of their group friends who lacked confidence. At first, these participants looked excited but also tired. Some participants showed a lack of confidence and problem-solving motivation and were lazy to defend answers. They are irresponsible for their answers but follow their more confident friends. Furthermore, in the self-reflection session, many less-confident participants cannot accept criticism gracefully. They are the last to answer questions, conform to be accepted in their group, and are not enthusiastic in group discussions. Therefore, they should be asked the reason why they solve the problem being studied to motivate the participant in PBL group.

The participants in the IBL group were not divided into groups. Instead, they formulate their problems, seek answers, and correct them using the material links shared by the facilitators. With the IBL method, they compare their abilities after learning with their own abilities before. They do not compare their abilities with others, either in the same group or different groups.

The third finding is that the converging learning style had a higher CT improvement than the approaches in the IBL group. The individual learning style convergence consists of abstract conceptualization and active experimentation, which means that individuals learn through thinking and action. People with convergent styles prefer experimenting with new ideas, conducting simulations, and working with practical applications [43]. People with convergent learning styles are problem-solvers and adept at finding practical solutions. Moreover, they prefer technical tasks and are less concerned with people and interpersonal aspects. People with converging learning styles are best at finding practical uses for ideas and theories. It is easy to arrive at technical decisions through the application of abstract concepts to real-life situations. A unified learning style enables special skills and technology. People with a converging learning 
style are able to use the left and right brain to think [56]. Furthermore, students with a converging learning style have advantages in applying theory to problem-solving [57]. This makes participants with the highest converging learning styles improve their critical thinking skills.

The limitation of this study is that the learning style is the participant's choice, not something that is taught by the facilitator in IBL. Thus, the type of person with a converging learning style will be excellent at implementing IBL and improving their critical thinking. As for other learning styles (assimilating, accommodating, and diverging), although not as good as the converging type in implementing IBL, they still significantly improve critical thinking. We suggest further research on IBL implementation with a larger and unlimited sample size for prospective teachers not only who have low and very low critical thinking.

\section{CONCLUSION}

From this study, it can be concluded that Inquiry-based learning (IBL) improves the critical thinking skills of prospective teachers. This increase in critical thinking abilities is higher than problem-based learning methods. IBL increases the entire group of prospective teachers, on the other hand, the PBL method is not suitable for groups with very low CT. Prospective teachers with a converging learning style find it easier to implement IBL so that it results in the highest increase in CT.

\section{CONFLICT OF INTEREST}

The authors declare no conflict of interest.

\section{AUTHOR CONTRIBUTIONS}

Damajanti Kusuma Dewi is the head of the research, contributing to the research planning, implementation, collection of data, and the main author. Wayan Ardhana contributed to directing the implementation of IBL as well as supervising data collection. Irtadji contributed to collecting data processes and analyzing research results. Tutut Chusniyah contributed to directing research methods, participated in supervising research IBL and PBL implementation, and analyzing statistical results. Ambar Sulianti contributed to directing research design, analyzing statistics, implementing cognitive-affective learning processes from a biopsychological perspective, and as a correspondence author.

\section{REFERENCES}

[1] OECD (Organization for Economic Co-Operation and Development), "What 15-year-old students in Indonesia know and can do," Program Int Student Assess Result from PISA 2018, 2018, pp. 1-10.

[2] B. Tanujaya, J. Mumu, and G. Margono, "The relationship between higher order thinking skills and academic performance of student in mathematics instruction," International Education Studies, vol. 10, no. 11, pp.78-85.

[3] G. S. Pratama and H. Retnawati, "Urgency of higher order thinking skills (HOTS) content analysis in mathematics textbook," Journal of Physics: Conference Series, 2018, p. 012147.

[4] N. O. Regina, "Classroom management: A tool for achieving quality secondary school education in Nigeria," Int J Educ., vol. 6, no. 2, pp. $58-68,2014$
[5] Z. N. Afif, N. Ulfatin, A. Imron, and B. B. Wiyono, "The Improvement of teachers' pedagogical competence in recognising students characteristics with neuro-linguistic programming (NLP) in Indonesia," Int J Innov Creat Chang, vol. 13, no. 8, pp. 762-80, 2020.

[6] S. R. Yuliati and I. LestarI, "Higher-order thinking skills (hots) analysis of students in solving hots question in higher education," Perspekt Ilmu Pendidik, vol. 32, no. 2, pp. 181-8, 2018.

[7] J. L. S. Ramos, B. B. Dolipas, and B. B. Villamor, "Higher order thinking skillss and academic performance in physics of college students: A regression analysis," Int J Innov Interdiscip, vol. 4, no. 48 , pp. $48-60$.

[8] S. Prayogi, L. Yuanita, and L. Wasis, "Critical inquiry-based learning: A model of learning to promote critical thinking among prospective teachers of physic," J Turkish Sci Educ., vol. 15, no. 1, pp. 43-56, 2018.

[9] J. Jailani, S. Sugiman, and E. Apino, "Implementing the problem-based learning in order to improve the students' HOTS and characters," J Ris Pendidik Mat., vol. 4, no. 2, pp. 247-259, 2017.

[10] H. Retnawati, H. Djidu, Kartianom, E. Apino, and R. D. Anazifa, "Teachers' knowledge about higher-order thinking skills and its learning strategy," Probl Educ 21 st Century, vol. 76, no. 2, pp. 215-30, 2018.

[11] T. S. Susiani, M. Salimi, and R. Hidayah, "Research based learning (RBL): How to improve critical thinking skills?" SHS Web of Conferences, 2018, p. 00042.

[12] Y. L. Lee, "Nurturing critical thinking for implementation beyond the classroom: Implications from social psychological theories of behavior change," Think Ski Creat., no. 27, pp. 139-46.

[13] R. Ramezani, E. E. Larsari, and M. A. Kiasi, "The relationship between critical thinking and EFL learners' speaking ability," English Language Teaching, vol. 9, no. 6, pp. 189-198, 2016.

[14] J. C. Hong, M. Y. Hwang, K. H. Tai, and C. R. Tsai, "An exploration of students' science learning interest related to their cognitive anxiety, cognitive load, self-confidence and learning progress using inquiry-based learning with an iPad," Res Sci Educ., vol. 47, no. 6, pp. 1193-212, 2017

[15] B. K. B. Putra, B. A. Prayitno, and Maridi, "The effectiveness of guided inquiry and instad towards students critical thinking skills on circulatory system materials," J Pendidik IPA Indones., vol. 7, no. 4, pp. 476-82, 2018.

[16] W. Wartono, M. N. Hudha, and J. R. Batlolona, "How are the physics critical thinking skills of the students taught by using inquiry-discovery through empirical and theorethical overview?" Eurasia J Math Sci Technol Educ., vol. 14, no. 2, pp. 691-697, 2018.

[17] L. A. Borovay, B. M. Shore, C. Caccese, E. Yang, and O. Hua, "Flow, achievement level, and inquiry-based learning," $J$ Adv Acad., vol. 30, no. 1, pp. 74-106, 2019.

[18] P. Pajkossy, "Cognitive control, trait anxiety and trait worry," M.Psi thesis, Dept. Psychology. Eng., Budapest University of Technology and Economics, Budapest, Hungary, 2014.

[19] J. D. Bremner, "Traumatic stress: Effects on the brain," Dialogues Clin Neurosci., vol. 8, no. 4, pp.1-18, February 2006.

[20] A. Sulianti, Y. Yulianti, R. Riswanda, A. D. Amalia, and R. Anwar, "Dhikr to Manage Epileptiform Activity in a Teenager with Depressive Disorder," IOP Conference Series: Materials Science and Engineering, 2018, p. 012015

[21] Zoning-Based Higher Order Thinking Skills Learning Handbook, Direktorat Jendral Guru dan Tenaga Kependidikan, Jakarta, 2018, pp. $1-87$.

[22] I. Kurniasih and B. Sani, 2013 Curriculum Implementation Concepts and Applications, Jakarta, Indonesia: Kementrian Pendidik dan Kebud, 2014, pp. 1-162.

[23] K. M. Wong, "A design framework for enhancing engagement in student - Centered learning: own it, learn it, and share it" by Lee and Hannafin (2016): An international perspective," Educ Technol Res Dev., vol. 69, no. 1, pp. 93-96, 2021.

[24] S. H. V. Wong and Y. Kowitlawakul, "Exploring perceptions and barriers in developing critical thinking and clinical reasoning of nursing students: A qualitative study," Nurse Educ Today, vol. 95, pp. 104600,2020

[25] A. Günay, İ. Didem, and E. Özcan, "Concept cartoons supported problem based learning method in middle school science classrooms," J Educ Learn, vol. 5, no. 2, pp. 272-84, 2016.

[26] A. Maharani and Laelasari, "Experimentation of spices learning strategies with the method of problem-based learning (pbl) to build motivation and the ability to think logically for vocational school students," J Math Educ., vol. 6, no. 2, pp. 149-156, 2017. 
[27] L. E. C. Bravo, G. M. T. Bermudez, and J. I. R. Molano, "Design and application of a creative strategy based on the method of problem-based learning (PBL) in engineering students," International Workshop on Learning Technology for Education in Cloud, 2018, pp. 168-180.

[28] J. R. Savery, Overview of Problem-based Learning: Definitions and Distinctions, USA: Library of Congress, 2015.

[29] D. R. Sitio, E. Surya, and W. Rajagukguk, "Differences ability of problem solving and self-efficacy student math of learning jigsaw based culture of batak toba with direct learning," pp. 177-180,, 2018.

[30] M. A. Ghufron and S. Ermawati, "The strengths and weaknesses of cooperative learning and problem-based learning in EFL writing class: Teachers' and students' perspectives," Int J Instr., vol. 11, no. 4, pp. 657-72, 2018.

[31] F. E. Aparicioting, D. M. Slater, and E. U. Kurz, "Inquiry-based learning (ibl) as a driver of curriculum : A staged approach," Papers on Postsecondary Learning and Teaching, vol. 3. pp. 44-51, 2019.

[32] J. Siew J, Y. Chong, M. Siew, F. Chong, M. Shahrill, and N. A. Abdullah, "Implementing inquiry-based learning and examining the effects in junior college probability lessons," J Math Educ., vol. 8, no. 2 , pp. 157-164, 2017.

[33] G. Silm, K. Tiitsaar, M. Pedaste, Z. C. Zacharia, and M. Papaevripidou, "Teachers' readiness to use inquiry-based learning: an investigation of teachers' sense of efficacy and attitudes toward inquiry-based learning," Science Education International, vol. 28, no. 4, pp. 315-325, 2017.

[34] A. P. Fowler, "We've got the' hots' for changing teacher misconceptions of learning styles : a mixed-methods approach," Ph.D. dissertation, Dept. Counseling and Human Development, Louisville Univ., Louisville, MA, 2020.

[35] T. Magfirah, "Students' reading and listening comprehension based on their learning styles," Int J Educ., vol. 10, no. 2, pp. 107-113, 2018.

[36] D. Samsudin and T. I. Hardini, "The influence of learning styles and metacognitive skills on students' critical thinking in the context of student creativity," Int J Educ., vol. 11, no. 2, pp. 117-124, 2019.

[37] D. Durães, F. de la Prieta, and P. Novais, "Enriching behavior patterns with learning styles using peripheral devices," Knowl Inf Syst., vol. 60 pp. 1645-1662, 2018

[38] R. D. Costa, G. F. Souza, R. A. M. Valentim, and T. B. Castro, "The theory of learning styles applied to distance learning," Cogn Syst Res., vol. 64, pp. 134-145, 2020.

[39] A. E. Labib, J. H. Canós, and M. C. Penadés, "On the way to learning style model's integration: A Learner's characteristics ontology," Comput Human Behav., vol. 37, pp. 433-445, 2017.

[40] Y. Dilekli, "The relationships between critical thinking skills and learning styles of gifted students," Eur J Educ Stud., vol. 3, no. 4, pp. 69-96

[41] H. E. Sadagheyani and F. Tatari, "First-year students' learning styles in neyshabur university of medical sciences in2019: A cross-sectional study," PalArch's Journal of Archaeology of Egypt/Egyptology, vol. 17 no. 7, pp. 8729-8740, 2017.

[42] A. O. A. Awofala, R. F. Lawal, and A. A. Arigbabu, "Future teachers' mathematics cognitive failures and their learning styles," Int J Teach Learn Math, vol. 3, no. 1, pp. 12-22, 2020.

[43] M. D. Omeodu, "Investigating students' academic performance in physics based on kolb's experiential learning model in rivers state," Asian J Adv Res Reports, vol. 12, no 4, pp. 9-17, 2020.

[44] M. D. Natalia and M. F. Azzajjad, "The effectiveness of student centre learning in experiment method on acid and base solution to increase student achievement," J Appl Sci Eng Technol Educ., vol. 2, no. 1, pp. $0-4,2020$.

[45] C. H. Padmanabha, "Critical thinking: conceptual framework," J Educ Psychol., vol. 11, no. 4, pp. 45-53, 2018.

[46] N. M. Takaloo and M. R. Ahmadi, "The effect of learners' motivation on their reading comprehension skill: A literature review," Int $J$ Res English Educ., vol. 2, no. 3, pp. 10-21, 2017.

[47] A. To, S. Ali, G. F. Kaufman, and J. Hammer, "Integrating curiosity and uncertainty in game design," In: Digra/fdg, 2016.

[48] P. Oudeyer, J. Gottlieb, and M. Lopes, Intrinsic Motivation, Curiosity, and Learning: Theory and Applications in Educational Technologies, 1st ed., ch. 11, pp. 1-28, 2016.

[49] G. Brod and J. Breitwieser, "Lighting the wick in the candle of learning: generating a prediction stimulates curiosity," NPJ Sci Learn, vol. 4, no. 1, pp. 1-7, July 2019.

[50] J. Siburian, A. D. Corebima, Ibrohim, and M. Saptasari, "The correlation between critical and creative thinking skills on cognitive learning results," Eurasian J Educ Res., no. 81, pp. 99-114, 2019.
[51] M. Eka, P. Ramandha, Y. Andayani, and S. Hadisaputra, "An analysis of critical thinking skills among students studying chemistry using guided inquiry models," AIP Conference Proceedings, 2021, pp. 080007.

[52] Husni, "The effect of inquiry-based learning on religious subjects learning activities: An experimental study in high schools," J Penelit Pendidik Islam, vol. 8, no. 1, pp. 43-54, 2020.

[53] H. Suwono, H. E. Pratiwi, H. Susanto, and H. Susilo, "Enhancement of students' biological literacy and critical thinking of biology through socio-biological case-based learning," J Pendidik IPA Indones., vol. 6 , no. 2, pp. 213-220, 2017

[54] A. Syarkowi, R. Sujanem, S. Poedjiastuti, B. Jatmiko, A. Istiqomah, and K. S. Perbowo, "Effectiveness of guided inquiry learning model to improve students' critical thinking skills at senior high school Effectiveness of guided inquiry learning model to improve students critical thinking skills at senior high school," Journal of Physics. Conference Series, 2017, p. 012049.

[55] D. Chen and J. Rattray, "Transforming thinking through problem-based learning in the news media literacy class: Critical thinking as a threshold concept towards threshold capabilities," Practice and Evidence of the Scholarship of Teaching and Learning in Higher Education, vol. 12, no. 2, pp. 272-293, 2017.

[56] F. F. Cheng, C. C. Chiu, C. S. Wu, and D. C. Tsaih, "The influence of learning style on satisfaction and learning effectiveness in the asynchronous web-based learning system," Libr Hi Tech., vol. 35, no. 4, pp. 473-89, 2017.

[57] I. B. N. Sudria, I.W. Redhana, I. M. Kirna, and D. Aini, "Do Kolb's learning styles under inductive guided-inquiry learning affect on learning outcomes?" Int J Instr., vol. 11, no. 1, pp. 89-102, 2018.

Copyright $\odot 2021$ by the authors. This is an open access article distributed under the Creative Commons Attribution License which permits unrestricted use, distribution, and reproduction in any medium, provided the original work is properly cited (CC BY 4.0).

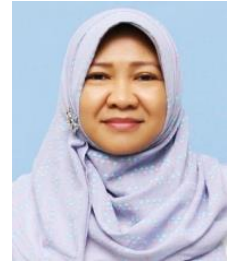

Damajanti Kusuma Dewi was born in Madiun on October 27, 1970. She was graduated from the University of Putra Bangsa Surabaya majoring in psychology. Then she had a magister's degree in psychology on psychometry from Gadjah Mada University Jogjakarta Indonesia in 1998. At present, she had a doctoral degree at Universitas Negeri Malang.

She was a vice of the psychology program at Universitas Negeri Surabaya She is also active in developing technology for education. Digital storytelling was her project in 2012. She had a publication in a journal of educational technology applying digital storytelling in blended learning to improve communication ability. Applying cooperative learning to improve math, developing a science module to improve academic achievement are two of her publications in 2011. She is also active in social engagement by having guidance for traditional playing among children in Surabaya.

Dewi was active in the psychology association in Indonesia. She also had some research on online guidance and counseling. She made a module on project-based learning to improve higher-order thinking in 2015 and create a profile for teachers of early childhood education. She is one of the committees in the early childhood education association specialized in curriculum development.

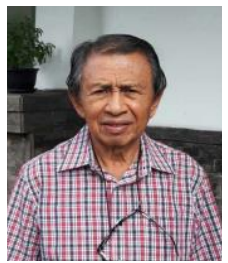

Wayan Ardhana was born in Bali Indonesia on May 20, 1937. He had a degree in diploma primary teacher trainer from Moray House College of education Edinburgh Scotland in 1975. Then he had a Master of Art, curriculum, and instruction from the University of Northern Colorado in 1978. He had a doctoral program at a teacher training program in Malang in 1983. He becomes a professor in education in 1986 by having a speech about the attribution of success and failure causes of academic achievement.

He had been teaching in Universitas Negeri Malang up to the present. even though he had been retired from a government employee, he was still teaching. He had experience in managing staff such as the vice dean of education faculty since 1966-1969, and vice dean of the postgraduate program.

He was an expert in educational psychology and learning technology. He also elaborated on research methods and statistics in education. Researches related to innovative learning was his project. Basic in education and statistics for education were books written by prof Aradhana. 


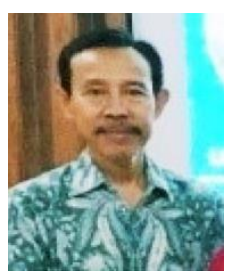

Irtadji was born in Blitar on August 17, 1953. He was graduated from IKIP Malang, a teacher institute majoring in school counseling in 1980. Then he had a magister in educational psychology from the University of Indonesia in 1993. He had a doctoral degree from Universitas Negeri Malang in 2012 Educational psychology was a specialization for his doctoral program.

He was of a lecturer at Universitas Negeri Malang. He is not only a lecturer but also a trainer for teachers. Developing a model of creative teaching for teachers in east java Indonesia was his research in 2015. It was the result of his projects in two years; 2014-2015. Involving students at school to be creative also his project in 2011 until being published.

Dr. Irtadji was active in promoting creativity both on teachers' and students' levels by having a seminar. He also had given some counseling programs to society through some cooperated programs with the local government. Besides, the selection process for students has also become his project since 2013. He joined the government committee to make a selection program for students registering for school. Designing teacher training at some elementary schools also one of his activities.

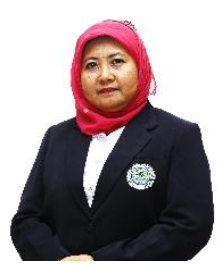

Tutut Chusniyah was born in Lumajang East Java Indonesia on June 2, 1964. She was graduated from Airlangga University Surabaya Indonesia in 1993 majoring in psychology. She had magister in psychology from the University of Indonesia in 2004 The structural model of holy violence was her thesis for her magister degree. Since she was interested in social psychology, she had a doctoral degree from the same university in 2012 and having a dissertation with the title "psychological needs, Islamic ideology, and group identity as a predictor of Khuilafah Syriah application."

She began her career as a lecturer in the psychology faculty in 1998 in Universitas Negeri Malang. She has been teaching some lectures; politics psychology, social psychology, and environmental psychology. She also becomes a promotor and advisor for students having a thesis and dissertation.

At present, she was a vice-dean at Universitas Negeri Malang managing the faculty of psychology.

Dr. Chusniyah was active in becoming a speaker at an international conference. In the last five years, she had some researches related to Islamic fundamentalist. In 2010, she collaborated having a research about defending religious world views after threats in Australia and Indonesia. Then in 2011, she had a discourse analysis on the attitude towards democracy and the Islamic system. She contributed to a book chapter in 2018 writing about Malaysian and Indonesian adolescents' resiliency and relationships with gratitude and happiness. He was also a member of the social psychology association in Indonesia

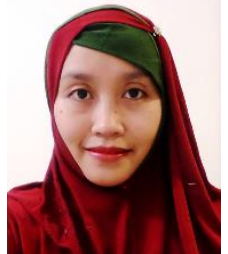

degree.

She has teaching experience at Jenderal Achmad Yani University, Indonesian Education University, and now works as a lecturer at the Psychology Faculty of UIN Sunan Gunung Djati Bandung, West Java. She has international publications in the field of education about the Jigsaw cooperative learning method in 2019, habit of happy brain in 2018, and various writings on neurocognitive sciences. She also has recognition experiences as a speaker in various outreach to the community.

Dr. Sulianti has been active as a speaker at various international conferences. In the last five years, she has conducted several studies related to health psychology, parasitology, cognitive neuroeducation, and biopsychology. She has produced 17 intellectual property rights since 2017 . She is a lecturer with lots of expertise and has a wide range of competency certificates including a national certification as instructor of learning methods. 